\title{
Community Character Education Society 5.0 and Future Management
}

\author{
Chairul Fauzi ${ }^{1}$, Siti Mayang Sari ${ }^{2}$, Winning Amintas KartikaWaruwu ${ }^{3}$, Hendri Putra ${ }^{4}$, \\ Rosmala Dewi ${ }^{5}$ \\ \{khairulfauzi94@gmail.com¹,Sitimayangsari30@gmail.com²,winningwaruwu95@gmail.com³ \\ hendriputra2378@gmail.com ${ }^{4}$,rosdw@yahoo.com ${ }^{5}$ \} \\ ${ }^{1}$ Sekolah Tinggi Ilmu Hukum Muhammadiyah Takengon, Indonesia \\ ${ }^{2}$ STKIP Bina Bangsa Getsempena Meulaboh Aceh, Indonesia \\ ${ }^{3}$ AKPER Kesdam I/BB Medan, Indonesia \\ ${ }^{4}$ STKIP Muhammadiyah Takengon, Indonesia \\ ${ }^{5}$ Universitas Negeri Medan, Indonesia \\ *khairulfauzi94@gmail.com
}

\begin{abstract}
The progress and change of information technology that is so fast and fast must be balanced with character education and management in society 4.0 , because without being balanced with character education and management in the future implementation of society 5.0 , society tends to be exclusive and individualistic. With the progress and changes in information technology today, people feel they do not really need other human beings, because all work can be done through technology, on the one hand technological advances cannot be dammed and it is a necessity to be able to make a job easier and more efficient, but on the other hand others will give birth to ignorance and mutual disrespect between one individual and another individual, in this case the role of character education and future management, is needed in building towards society 5.0.
\end{abstract}

Keywords: Character Education, Society 5.0, Future Management

\section{Introduction}

Society 5.0 is an era of information technology that refers to a new type of society in which innovation in science and technology occupies the top place in all fields, in today's society 5.0, every human being is very dependent on technology in both information and communication and even almost every job using technology, with the aim that every job can be done easily and efficiently so that human labor is not needed [1]. Community education 5.0 today, every educator and educated person is very dependent on technology both in the field of information and communication and even almost every process of teaching and learning using technology, with the aim of streamlining programs and methods of learning with technology that are carried out easily and efficiently so that PBM (Learning and Teaching Process) goes according to the curriculum. This is where the University attempts to change learning patterns for future management in this technological era.

The Japanese Prime Minister officially launches "Society 5.0". This is a human-centered and technology-based concept. Society 5.0 achieves a high degree of convergence between virtual space and physical space. In the past information society (Society 4.0 ), people will 
access database services in cyberspace through the internet and search, retrieve, and analyze information or data. In the concept of "Society 5.0" humans will play a bigger role by transforming big data into a new wisdom that ultimately increases the ability of humans to open opportunities for other humans to achieve a better and meaningful life [2]. This has an impact on education in the current management sphere which analyzes processes on educational patterns, builds conceptual frameworks of competent work, identifies underlying principles and builds management theory using a technological future management approach.

Facing society 5.0 era of the industrial revolution, in fact lecturers as stakeholder education in the delivery of material are not only based on curriculum guidelines, but must be able to give examples of the material delivered by utilizing current technological facilities. While students are not only required to understand the material presented but also must utilize technology. Character education has a higher meaning than moral education because character education is not only related to right or wrong, but how to instill habits about good things in life so that children have a high awareness and understanding and care and commitment to establish virtues in daily life [3].

In order not to lose the noble character of society in the era of 5.0 it is necessary to have efforts to maintain it through management to regulate the use of information technology in a good, intelligent and in accordance with needs, if the information technology is used intelligently then the value of the noble character can automatically be maintained, the value noble characters include attitudes of caring, tolerance, democratic, friendly and communicative[4]. The author has observed that in the absence of management and regulation in the intelligent use of information technology, the community tends to be exclusive, selfish, individualistic, and then indifference arises between one individual and another individual.

\section{Educational Character of the Future}

Character is the personality of a person formed from the internalization of various policies that are believed and used as a basis for perspective, thinking, acting and acting. Character terminology contains at least two things, namely values and personalities, these values can be developed through habits and role models. A person's habits are formed from actions carried out repeatedly every day, these actions are initially realized or intentional, but because so often the same actions are carried out, eventually the habit becomes reflexes that are not realized by the concerned [2]. Based on the quote above the character is a person's habit that is carried out spontaneously without the need for consideration and thought beforehand, and if the habit is carried out continuously then it will be a characteristic of someone who is very difficult to change again. Character is a way of thinking and behaving that characterizes each individual to live and work together, both within the scope of the family, community, nation and state". It can be concluded that individuals with good character are individuals who can make decisions and are ready to take responsibility for the consequences of the decisions they make [3].

Character education has a higher meaning than moral education because character education is not only related to right or wrong, but how to instill habits about good things in life so that children have a high awareness and understanding as well as caring and commitment to establish virtue in everyday life [6]. Character Education is as a Pillar of National Awakening with Achievement of the Highest Achievement of good character. The theme reminds us all about the nature of education that has been emphasized by our Father of National Education, Ki Hajar Dewantoro, who today we commemorate his birthday as 
National Education Day. Education, said Ki Hajar Dewantoro, is an effort to advance character (mental strength, character), mind (intellect) and the physical body of students [1].

\section{Future character formation}

Character building for the future of education cannot be done in an instant by giving advice to students, ordering, or instructing. Forming character patterns in students requires role models / role models in learning, patience, habituation, and repetition. The process of character education runs the flow of education experienced by students as a form of experience of personality formation through self-practice of the values of life, religion, and morals [1].

Table 1. Future Educational Management Strategies for society 5.0

\begin{tabular}{|c|c|c|}
\hline No & Important Strategy & Strategies \\
\hline 1 & Welfare & Providing Educational Facilities and welfare of educators. \\
\hline 2 & Policy in quality & Program major learning and quality requirements. \\
\hline 3 & $\begin{array}{l}\text { Management } \\
\text { Responsibilities }\end{array}$ & Responsible for the implementation of Higher Education Management \\
\hline 4 & Quality Organization & $\begin{array}{l}\text { authority and responsibility of the working group implementing the } \\
\text { quality system }\end{array}$ \\
\hline 5 & $\begin{array}{l}\text { Publication and } \\
\text { Marketing }\end{array}$ & $\begin{array}{l}\text { Documented as marketing materials such as brochures, advertisements, } \\
\text { leaflets, and leaflets }\end{array}$ \\
\hline 6 & Entrance Selection & $\begin{array}{l}\text { Documenting the results of the interview, interview, and the value of } \\
\text { the registration selection }\end{array}$ \\
\hline 7 & A curriculum design & for periodic review to increase the relevance of the world of work. \\
\hline 8 & $\begin{array}{l}\text { Implementation of the } \\
\text { curriculum }\end{array}$ & Detailed assessment and graduation criteria \\
\hline 9 & Learning Management & $\begin{array}{l}\text { Implementation of curriculum programs, which are organized } \\
\text { according to audit exposure in the role of the authorized team }\end{array}$ \\
\hline 10 & $\begin{array}{l}\text { Staff training and } \\
\text { development }\end{array}$ & $\begin{array}{l}\text { Establish procedures for staff selection, performance measurement, } \\
\text { innovation improvement and career development policies }\end{array}$ \\
\hline 11 & $\begin{array}{l}\text { Monitoring and } \\
\text { Evaluation }\end{array}$ & Achievement of review meetings, making achievement of internal audit \\
\hline 12 & $\begin{array}{l}\text { Administrative } \\
\text { Arrangements }\end{array}$ & $\begin{array}{l}\text { The process of controlling learning documents such as RPP and } \\
\text { Syllabus and records of exam results and achievements. }\end{array}$ \\
\hline 13 & $\begin{array}{l}\text { Institutional } \\
\text { Management }\end{array}$ & $\begin{array}{l}\text { Review Having a way of evaluating the overall performance of } \\
\text { Educators. }\end{array}$ \\
\hline
\end{tabular}




\section{Research methods}

The method used in this research is R\&D method that is produced from this research is a policy about attitudes in the development of character society 5.0 especially in student education and how to manage the future that can better regulate the use of information technology intelligently in society and in accordance with global needs[5].

Data collection techniques in this study were participatory observation. In this observation the researcher was directly involved in daily activities with students of the Law School. As a sample being observed, 50 psychology study program odd semester students were used as research data sources, and analyzing data descriptively. Descriptive statistics can be used if the researcher only wants to describe the sample data and does not want to make conclusions that apply to the population where the sample was taken.

\section{Results and Discussion}

Character is the attitude of a person who is displayed in a manner that is continual, both the attitude in a positive form and in a negative form. The development and implementation of character education in the community of habituation and example is a very important factor, because it is an embodiment of the character itself. In Islamic terminology, character is better known as moral, moral structure must be based on divine knowledge, which is derived from human values and based on science, therefore character formation needs to be preceded with knowledge and can be sourced from religious, social knowledge and culture [2,7]. Based on the above quotation, it can be understood that character is identical with morals, so that characters are universal human behavioral values which include all human activities, both in the context of relating to God, with himself, with fellow human beings and with their environment, manifested in the mind, attitudes, feelings, words and deeds based on religious norms, law, karma, culture and customs. Good character is related to knowing the good, loving the good and act good. Knowing the good means being able to understand and distinguish between good and bad $[3,8]$. Knowing the good means developing the ability to conclude or summarize a situation and choose a good thing to do, and then do it.

If every individual knows good, and loves the good, then certain character values in society such as caring, honesty, mutual respect, mutual respect, tolerance, democratic, responsibility, friendly and communicative are very easy to develop and implement, because in essence in the development of character education is inseparable from moral knowledge, moral feelings, and moral actions, so that universal behavioral values that cover all aspects of life, both behavioral values related to God and behavioral values related to fellow human beings. In the context of society 5.0 character education and the development of universal behavioral values are important to do, and are a big agenda to be planned and implemented at this time and in the future, because the progress of information technology is so rapid and maybe the negative impact it causes can only be dammed by the application and development of character values in society. 
Character education is a system of developing the values of Fitrah to school members which includes the components of knowledge, awareness and willingness and actions to implement them [2,9]. In character education in schools all components must be involved, including the education component itself, which includes curriculum content, learning and assessment processes, relationship quality, subject management, school management, implementation of non-curricular activities and activities, empowering facilities and infrastructure, as well the work ethic of all residents and the school environment. Character is a combination of morals, ethics, and morals [3]. Moral is more focused on the quality of human actions, actions, or behavior. Character education is the formation of a moral person by creating structures and environments that help the moral growth of individuals. This requires the public to actualize character education in educational institutions 3. Research Results From the results of the study with 50 respondents, using the SPSS

Table 2. Simultaneous Test

\begin{tabular}{llrrrrr}
\multicolumn{8}{c}{ ANOVA $^{\mathrm{a}}$} \\
\hline Model & \multicolumn{1}{c}{ Sum of Squares } & df & Mean Square & \multicolumn{1}{c}{ F } & \multicolumn{1}{c}{ Sig. } \\
\hline 1 & Regression & 6076.771 & 3 & 2025.590 & 24.006 & $.000^{\mathrm{b}}$ \\
& Residual & 10716.023 & 127 & 84.378 & & \\
& Total & 16792.794 & 130 & & & \\
\hline
\end{tabular}

a. Dependent Variable: Lecturer Performance

b. Predictors: (Constant), Campus environment, discipline, learning motivation

This study has more than 1 independent variable, it is necessary to do the Anova test to test the effect of the independent variables simultaneously on the dependent variable. Based on table 4.3 above the significance value indicates the value of 0,000 with a calculated $F$ value $(24,006)$ greater than the F table $(8.5)$. Thus it can be concluded that the campus environment variable, student discipline and learning motivation together influence the variable performance of lecturers at the tertiary institution and the effect is significant. In other words, the above model has fulfilled the feasibility of the model and character that is applied can be continued as applied to improve the quality of higher education management efforts to carry out community education 5.0 character community management.

Table 3. R Square Test

\begin{tabular}{|c|c|c|c|c|}
\hline \multicolumn{5}{|c|}{ Model Summary } \\
\hline Model & $\mathbf{R}$ & R Square & $\begin{array}{c}\text { Adjusted R } \\
\text { Square } \\
\end{array}$ & $\begin{array}{c}\text { Std. Error of the } \\
\text { Estimate }\end{array}$ \\
\hline 1 & $.602^{\mathrm{a}}$ & .362 & .347 & 9.186 \\
\hline
\end{tabular}

Based on table 3 above the value of $\mathrm{R}$ Square is at the level of 0.362 which means that the variables of learning motivation (X1), discipline (X2) and campus environment (X3) contribute to the influence of lecturer performance $(\mathrm{Y})$ by $36.2 \%$ and the remaining $63.8 \%$ influenced by other factors which cannot be examined in this study. Because the value of the contribution of the influence is still relatively small, $(36.2 \%)$ it can be said that there is still a large research room that might contribute to the performance of lecturers on the assessment of 
student character by looking at motivation to learn, discipline, and the environment in campus, so that the future management of the student will be created.

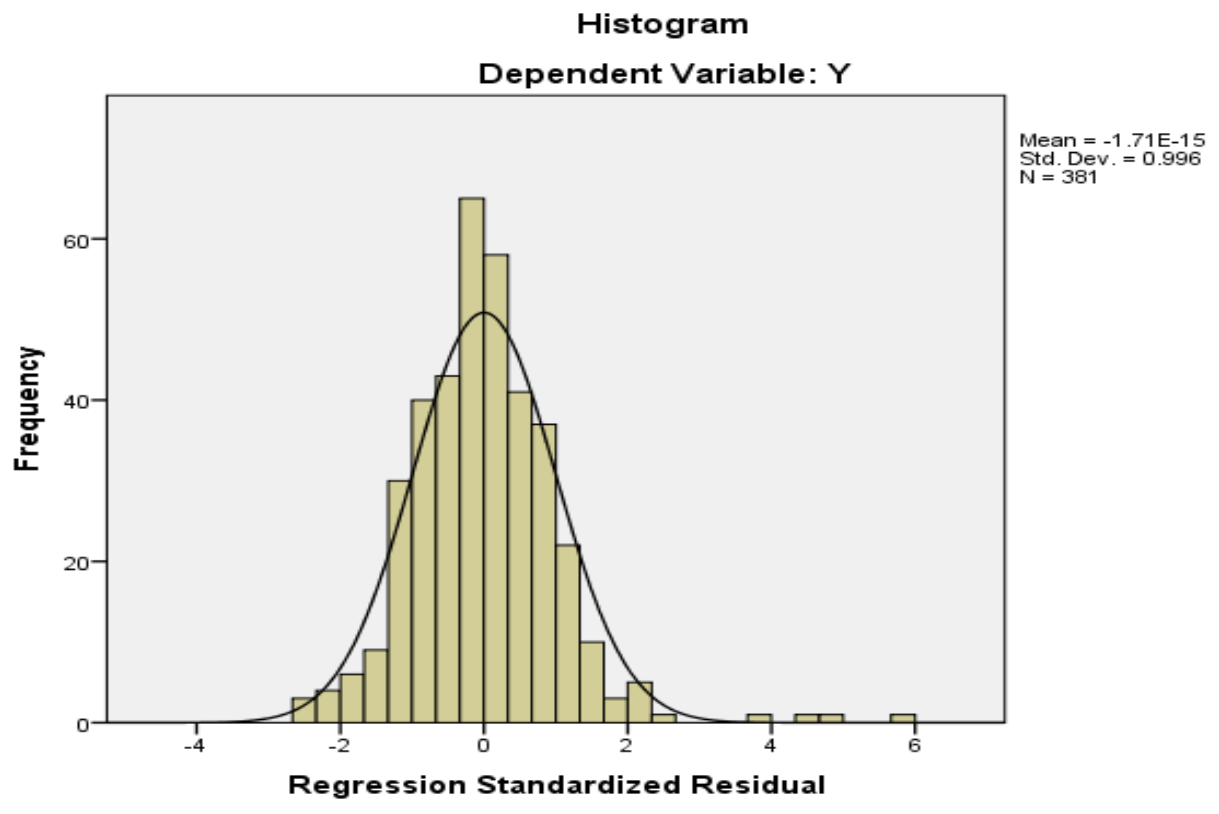

Fig 1. Histogram

To test the normality of the bars there must be some on the curve shape, not shifting right or left.

\section{Conclusion}

Lecturer performance is very influential on the future character of students. Discipline and motivation to learn in society 5.0 have an impact on increasing the character of students. Factors underlying human character / behavior are based on religious, cultural, legal / constitutional norms, customs and aesthetics. Character education is a planned effort to make students know, care and internalize values so that students behave as human beings. Character education is a system of instilling behavioral values (characters) to school members which includes components of knowledge, awareness or will, and actions to carry out these values, both towards God Almighty (YME), oneself, others, the environment , and nationality so that we are human beings. Character education at the institutional level leads to the formation of school culture, the values that underlie behavior, traditions, daily habits, and symbols that are practiced by all school residents, and the community around the school. School culture is a characteristic, character or character, and the image of the school in the wider community (Character education training paper). 


\section{References}

[1] Zubaedi. Desain Pendidikan karakter konsepsi dan Aplikasinya dalam Lembaga Pendidikan. Jakarta: Kencana Prenada Media Group. (2013).

[2] Kurniawan. Pendidikan Karakter konsepsi dan Implementasinya secara terpadu di lingkungan keluarga, sekolah, Perguruan Tinggi dan Masyarakat. Yogyakarta: Ar-ruzz Media. (2013).

[3] Moh. Mustari. Manajemen Pendidikan Era Globalisasi. Penerbit Raja Grafika Persada Jakarta. (2014).

[4] Fathurrahman, Suryana, dan Fatriany. Pengembangan Pendidikan Karakter. Bandung: PT Refika Aditama. (2013).

[5] Sugiono. Metode Penelitian Pendidikan. Bandung: Alfabeta. (2010).

[6] Zahri Harun. Manajemen Pendidikan Karakter. Jurnal Pendidikan Karakter FKIP Universitas Syiah Kuala. (2013).

[7] Andri Pitoyo. Lesson Study Sebagai Upaya Peningkatan Keterampilan Menulis Karya Tulis Ilmiah Melalui Model Jigsaw Di Era Masyarakat Society 5.0. Seminar Nasional Bahasa dan Sastra. (2019).

[8] Ajad Sudrajat. Mengapa Pendidikan Karakter. Jurnal Pendidikan Karakter FIS Negeri Yogyakarta. (2011).

[9] Zahri Harun. Manajemen Pendidikan Karakter. Jurnal Pendidikan Karakter FKIP Universitas Syiah Kuala. (2013). 